Desy Dwi Cahyani : Pengaruh Metode Zilgrei pada Ibu Inpartu Primigravida terhadap Pembukaan Servik Kala I Fase Aktif di RSUD Pare Kabupaten Kediri

\title{
Status Gizi Anak dengan Pertumbuhan dan Perkembangan Anak Usia 0 - 2 Tahun di Wilayah Kerja Puskesmas Tomo Kabupaten Sumedang Tahun 2013
}

Wulan Nur Insani ${ }^{1}$ Teni Nur Latifah ${ }^{2}$

${ }^{1,2}$ Akademi Kebidanan Respati Sumedang

\begin{abstract}
Abstrak
Menurut Departemen Kesehatan RI tahun 2006 bahwa 16\% anak Indonesia mengalami gangguan perkembangan baik perkembangan motorik halus dan kasar, gangguan pendengaran, kecerdasan kurang dan keterlambatan bicara. Tujuan penelitian ini adalah untuk mengetahui status gizi anak terhadap pertumbuhan dan perkembangan anak usia 0-2 tahun di wilayah Kerja Puskesmas Tomo Kecamatan Tomo Kabupaten Sumedang tahun 2013. Jenis penelitian ini kuantitatif dengan pendekatan cross sectional, untuk mengamati hubungan antara pengetahuan, pendidikan, pekerjaan, paritas, sikap, umur ibu, dan status gizi anak. Sampel yang dibutuhkan 100 orang dengan metode simple random sampling. Analisis bivariat yaitu uji statistik chi square untuk mengetahui faktor yang berhubungan, dan multivariat yaitu uji statistik regresi logistik untuk mencari faktor dominan. Hasil didapatkan pertumbuhan dan perkembangan yang sesuai sebanyak $86 \%$ dan tidak sesuai sebanyak $14 \%$. Pada uji bivariat variabel yang berhubungan adalah status gizi anak, pada analisis multivariat faktor yang dominan adalah status gizi anak P 0,000 dengan nilai OR=122,213 setelah dikontrol dengan variabel pekerjaan, pendidikan, sikap, umur dan informasi. Status gizi anak 122 kali mempunyai peluang pertumbuhan dan perkembangan anak sesuai karena status gizi anak berperan dalam pertahanan tubuh. Disarankan perlu ditingkatkan kembali upaya penanggulangan gizi kurang.
\end{abstract}

Kata kunci: Pertumbuhan dan perkembangan, Anak usia 0-2 tahun

Korespondensi :JL. Jalan Raya Bandung-Cirebon KM 75 Tomo Sumedang,No Tlp. (0233) 664000, Email:

teni_nhr08@yahoo.co.id,wulannurinsani@yahoo.co.id 


\title{
Nutritional Status Of Children with Growth and Development of Children Ages 0-2 Years in Puskesmas Tomo Sumedang District 2013
}

\begin{abstract}
According to the Depkes RI,2006 that $16 \%$ of Indonesian children experiencing developmental disorders both fine and grossmotor development, hearing impairment, lack of intelligence and speech delays. The purpose of this study is to identify the factors associated with the growth and development of children aged 0-2 years in Tomo Public Health Center of Sumedang District in 2013 period. This is quantitative research with cross sectional approach, to observe relations between knowledge, education, employment, parity, attitudes, maternal age, nutritional status, and information. 100 samples required by simple random sampling method. Bivariate analysis of the chisquare statistical test to investigate factors associated, and the multivariate logistic regression statistical tests to find out the dominant factor. The results obtained appropriate growth and developmentas much as $86 \%$ and does not appropriate much as $14 \%$. In the bivariate test variables that were related to nutritional status of children, on multivariate analysis the dominant factoris the nutritional status of children with $\mathrm{p}$ value of $0.000 \mathrm{OR}=122.213$ after controlled with variable occupation, education, attitude, age and information. 122 times the nutritional status of children has opportunities for growth and development of children corresponding for a child's nutritional status plays a role in the body's defenses. Need to be increased about prevention effort small nutrition is suggested.
\end{abstract}

Key words: Growth and development, children aged 0-2 years 


\section{Pendahuluan}

Pembangunan Nasional bisa berjalan lancar jika pembangunan kesehatan dilaksanakan dengan baik, karena pembangunan kesehatan merupakan salah satu indikator pembangunan Nasional. ${ }^{1}$ Tujuan utama pembangunan nasional adalah peningkatan kualitas Sumber Daya Manusia (SDM) yang dilakukan secara berkesinambungan. Upaya peningkatan kualitas SDM dimulai dengan perhatian utama pada proses tumbuh kembang anak sejak pembuahan sampai dengan usia dewasa muda. Pada masa tumbuh kembang ini, pemenuhan kebutuhan dasar anak seperti perawatan dan makanan bergizi yang diberikan dengan penuh kasih sayang dapat membentuk SDM yang sehat, cerdas dan produktif. ${ }^{1}$

Pembangunan kesehatan sebagai bagian dari upaya membangun manusia yang sehat, melakukan pembinaan kesehatan anak sejak dini melalui kegiatan kesehatan Ibu dan Anak. Mengacu pada UU No. 23 tahun 2002 tentang perlindungan anak adalah sejak di dalam kandungan hingga ia berusia 18 tahun. Anak mempunyai hak untuk hidup, tumbuh dan berkembang, mendapatkan perawatan, pelayanan kesehatan, stimulasi, pendidikan, perlindungan dari kekerasan serta pemenuhan hak-hak anak lainnya agar menjadi anak yang sehat, cerdas, berakhlak mulia serta berguna bagi dirinya, keluarga, masyarakat serta Negara. ${ }^{2}$ Penilaian perkembangan pada anak penting dilakukan terutama sampai usia 1 tahun untuk deteksi dini, agar bila ditemukan kecurigaan penyimpangan dapat dilakukan stimulasi dan intervensi dini sebelum terjadi kelainan.

Stimulasi perkembangan dan kelainan perkembangan anak semakin marak dibicarakan menyusul semakin banyak kasus yang ditemukan pada semua golongan. Sayangnya, kasus-kasus yang ditemukan tentang kelainan perkembangan sudah terlambat bahkan amat terlambat. Hal ini berdampak negatif bagi masa depan anak, beban bagi orang tua dan juga hilangnya potensi tenaga kerja dimasa depan. ${ }^{2}$ Anak merupakan generasi penerus suatu bangsa, dengan demikian dibutuhkan anak dengan kualitas yang baik agar tercapai masa depan bangsa yang baik. Anak usia prasekolah adalah suatu masa usia anak yang sangat berbeda dengan usia dewasa. Di dalam periode ini didapatkan banyak permasalahan kesehatan yang sangat menentukan kualitas anak di kemudian hari. Masalah kesehatan tersebut salah satunya gangguan perkembangan. Permasalahan kesehatan tersebut pada umumnya akan menghambat pencapaian prestasi pada peserta didik di sekolah. Sayangnya permasalahan tersebut kurang begitu diperhatikan baik oleh orang tua atau para klinisi serta profesional kesehatan lainnya. Pada umumnya mereka masih banyak memprioritaskan kesehatan anak Anak usia 0-2 Tahun. ${ }^{3}$

Menurut Depkes RI, 2006 bahwa 16\% anak indonesia mengalami gangguan perkembangan baik perkembangan motorik halus dan kasar, gangguan pendengaran, kecerdasan kurang dan keterlambatan bicara. Pertumbuhan dan perkembangan anak dipengaruhi oleh beberapa faktor seperti genetik, faktor lingkungan baik lingkungan prenatal maupun lingkungan postnatal. Dimana faktor yang paling berperan adalah faktor lingkungan terutama keluarga, karena keluarga adalah lingkungan pertama kali dikenal anak terutama ibu. Pengetahuan, sikap serta kemampuan ibu untuk bertindak dalam masa kritis perkembangan anak menjadi faktor yang sangat menentukan dalam proses pertumbuhan dan perkembangan anak. ${ }^{4}$

Menurut penelitian Paradis dan rekan - rekan yang melakukan survey terhadap orang tua 98,6\% dari mereka adalah ibu dari 10.000 Anak. Para orang tua ditanyai 11 pertanyaan untuk menguji pengetahuan mereka tentang perkembangan anak, hasilnya sepertiga dari responden menjawab secara tidak benar empat atau lebih pertanyaan, atau dengan kata lain sepertiga orang tua yang memiliki anak ternyata mempunyai sedikit pengetahuan tentang perkembangan. Status pekerjaan orang tua juga memberikan dampak terhadap perkembangan anak, hal ini berhubungan dengan kesempatan orang tua dalam memberikan stimulasi terhadap perkembangan anak, ibu yang bekerja mengurangi kesempatannya untuk memberikan stimulasi terhadap perkembangan anak, begitu juga sebaliknya dengan ibu yang tidak bekerja memiliki kesempatan yang lebih banyak untuk bersama anak. ${ }^{5}$

Ditinjau dari faktor anak, status gizi anak merupakan hal penting yang mempengaruhi pertumbuhan dan perkembangannya. Menurut 
dr. Soedjatmiko, 2007 pada masa anak usia 0-2 tahun otak seorang anak akan berkembang dengan sangat pesat yang nantinya akan mempengaruhi kecerdasan anak tersebut. Perkembangan kecerdasan, kreativitas dan perilaku akan tergantung dari kualitas fungsi otak. Agar perkembangan otak dapat berjalan secara optimal diperlukan asupan nutrisi yang berkualitas. ${ }^{6}$ Awal kehamilan merupakan titik nol perhatian terhadap anak, terutama dalam menjaga keterjaminan asupan gizi yang baik secara optimal, hingga setidaknya 1000 hari berikutnya. Pada dasarnya, di 1000 hari awal kehidupan, pertumbuhan dan perkembangan anak berlangsung secara cepat. Rentang 1000 hari awal kehidupan yang harus menjadi perhatian ini bukan tanpa alasan. Selama ini dipahami bahwa pertumbuhan anak yang berlangsung secara cepat terjadi pada masa-masa awal, yaitu tahun pertama dan kedua usia anak. ${ }^{6}$

Berdasarkan laporan profil kesehatan Kabupaten Sumedang tahun 2011, cakupan deteksi dini tumbuh kembang anak pra sekolah rata-rata masih rendah termasuk puskesmas Tomo yaitu 3,85\% sementara target deteksi dini tumbuh kembang adalah $70 \%$. Sebagai calon generasi penerus bangsa maka kualitas tumbuh kembang anak usia 0-2 tahun perlu mendapat perhatian serius diantaranya dengan cara deteksi dini dan intervensi dari penyimpangan tumbuh kembang anak.

\section{Metode}

Pendekatan penelitian yang digunakan adalah pendekatan kuantitatif dengan metode cross sectional. Sampel didapatkan dari rumus Lemeshow yaitu 100 orang ibu yang mempunyai anak usia 0-2 tahun. Analisis yang digunakan adalah analisis univariat, bivariat dengan uji statistik chi square dan multivariat dengan uji statistik regresi logistik sederhana.

\section{Hasil Penelitian}

Gambaran umum Pertumbuhan dan perkembangan anak dibagi menjadi dua kategori, yaitu sesuai dan tidak sesuai (Tabel 1).

Tabel 1Gambaran Umum Pertumbuhan dan Perkembangan Anak

\begin{tabular}{|c|c|c|c|c|c|c|c|}
\hline \multirow[t]{3}{*}{ No } & \multirow[t]{3}{*}{ Pertumbuhan } & \multicolumn{4}{|c|}{ Perkembangan } & \multicolumn{2}{|c|}{ Total } \\
\hline & & \multicolumn{2}{|c|}{ Sesuai } & \multicolumn{2}{|c|}{ Tidak sesuai } & \multirow[t]{2}{*}{$\mathrm{N}$} & \multirow[t]{2}{*}{$\%$} \\
\hline & & $\mathrm{N}$ & $\%$ & $\mathrm{n}$ & $\%$ & & \\
\hline 1 & Sesuai & 87 & 93,5 & 6 & 6,5 & 93 & 100 \\
\hline 2 & Tidak sesuai & 7 & 100 & 0 & 0,0 & 7 & 100 \\
\hline & Total & 94 & 94,0 & 6 & 6,0 & 100 & 100 \\
\hline
\end{tabular}

Berdasarkan tabel 1 dapat dilihat bahwa dari 100 anak usia $0-2$ tahun hampir sebagian besar memiliki pertumbuhan yang sesuai $(93,5 \%)$.
Gambaran umum status gizi dibagi menjadi dua kategori, yaitu Gizi kurang dan gizi baik (Tabel 2)

Tabel 2Status Gizi Anak

\begin{tabular}{llcc}
\hline No & \multicolumn{1}{c}{ Kategori } & N & \% \\
\hline 1 & Gizi Kurang & 8 & 8,0 \\
2 & Gizi Baik & 92 & 92,0 \\
\hline & Total & 100 & 100,0 \\
\hline
\end{tabular}

Berdasarkan tabel 2 tentang status gizi anak dapat dilihat bahwa hampir seluruh responden

Setelah didapatkan dilakukan hasil

uji statistik (tabel maka $3)$. dengan gizi baik sebanyak 92 orang $(92,0 \%)$.

Tabel 3Status Gizi Anak dengan Pertumbuhan dan Perkembangan Anak Pertumbuhan dan Perkembangan Anak Usia 0-2 Tahun Total Anai Tidak Sesug

\section{No Kategori} Tidak Sesuai

n $\%$

$1 \quad$ Gizi kurang

$\begin{array}{ccc}\mathbf{n} & \% & \mathbf{n} \\ 1 & 12,5 & 7\end{array}$

87,5

8

100,0

73,500




\begin{tabular}{lccccccc}
\hline & & & & & & $(8,0-674,8)$ \\
$2 \quad$ Gizi baik & 85 & 91,3 & 7 & 8,7 & 92 & 100,0 & \\
\hline Jumlh & 86 & 85,0 & 14 & 15,0 & 100 & 100,0 & \\
\hline
\end{tabular}

Tabel 3 menggambarkan hasil analisis hubungan antara status gizi baik dengan pertumbuhan dan perkembangan anak sesuai usia $0-2$ tahun, diperoleh bahwa ada sebanyak 84 $(91,3 \%)$ status gizi anak pertumbuhan dan perkembangan anak nya sesuai. Sedangkan diantara status gizi kurang, ada $1(12,5 \%)$ yang pertumbuhan dan perkembangan anaknya sesuai. Berdasarkan hasil uji statistik didapatkan nilai terdapat $\rho=0,000$. Hal ini berarti ada perbedaan proporsi pertumbuhan dan perkembangan anak usia 0 -2 tahun antara status gizi anak baik dengan status gizi anak kurang (ada hubungan yang signifikan antara status gizi anak dengan pertumbuhan dan perkembangan anak usia $0-2$ tahun). Dari hasil analisis diperoleh pula nilai $\mathrm{OR}=73,500$, artinya status gizi anak baik mempunyai peluang 73,5 kali pertumbuhan dan perkembangan anak sesuai dibanding dengan status gizi anak yang kurang.

\section{Pembahasan}

Masa anak dibawah lima tahun merupakan periode penting dalam tumbuh kembang anak karena pertumbuhan dasar yang berlangsung pada masa balita akan mempengaruhi dan menentukan perkembangan anak selanjutnya. Seperti diketahui bahawa tiga tahun pertama merupakan periode keemasan (golden period), yaitu terjadi optimalisasi proses tumbuh kembang ${ }^{7}$ Dalam pertumbuhan dan perkembangan anak memerlukan zat gizi agar proses pertumbuhan dan perkembangan berjalan baik. Zat - zat gizi yang dikonsumsi akan berpengaruh pada status gizi anak. Perbedaan status gizi balita dibawah tiga tahun memiliki pengaruh yang berbeda pada setiap perkembangan anak, apabila gizi seimbang yang dikonsumsi tidak terpenuhi, pencapaian pertumbuhan dan perkembangan anak terutama perkembangan motorik yang baik akan terhambat. $^{8}$

Berdasarkan hasil penelitian diketahui bahwa dari 100 responden terdapat 92 orang $(92,0 \%)$ dengan status gizi baik dan 8 orang $(8,0 \%)$ dengan status gizi kurang. Data ini menunjukkan bahwa sebagian besar anak usia 0-2 tahun memiliki status gizi baik. Kondisi ini mungkin dipengaruhi oleh pengetahuan, sikap serta tindakan ibu yang cukup baik dalam meningkatkan status gizi anaknya.

Dari hasil tabulasi silang menunjukkan bahwa jumlah anak yang status gizi baik dengan pertumbuhan dan perkembangan sesuai sebesar 91,3\% sedangkan jumlah anak yang status gizi kurang dengan pertumbuhan dan perkembangan sesuai sebesar $12,5 \%$.Berdasarkan hasil uji statistik diketahui bahwa terdapat hubungan yang signifikan antara status gizi dengan pertumbuhan dan perkembangan anak usia 0-2 tahun. Hasil ini sesuai dengan penelitian di wilayah kerja puskesmas gambirsari kota surakarta bahwa ada hubungan antara status gizi dengan perkembangan anak. ${ }^{9}$ Hasil ini juga sesuai dengan penelitian Choiunnisa bahwa ada hubungan antara status gizi dengan perkembangan motorik kasar anak. ${ }^{10}$ Hasil yang sama juga bahwa ada hubungan antara status gizi waktu lahir dengan perkembangan anak usia pra sekolah $^{11}$.

Status gizi atau pemenuhan kebutuhan nutrisi merupakan salah satu faktor yang mempengaruhi perkembangan, apabila kebutuhan nutrisi tidak atau kurang terpenuhi maka dapat menghambat pertumbuhan dan perkembangan.Seseorang yang memiliki status gizi bak atau normal maka refleksi yang diberikan adalah pertumbuhan normal, tingkat perkembangan sesuai dengan usianya, tubuh menjadi sehat, nafsu makan baik dan mudah menyesuaikan diri dengan lingkungan. ${ }^{11}$ Gizi pada balitaterutama diperlukan untuk mendukung pertumbuhan dan perkembangannya. Kurang terpenuhinya gizi pada anak akan menghambat sintesis protein DNA sehingga menyebabkan terhambatnya pembentukan sel otak yang selanjutnya akan menghambat perkembangan otak. ${ }^{12}$

\section{Simpulan}

Penelitian ini menyimpulkan adanya hubungan antara status gizi anak dengan pertumbuhan dan perkembangan anak. Artinya pertumbuhan dan perkembangan anak sangat dipengaruhi oleh tindakan ibu dalam memenuhi kebutuhan gizi anaknya. Kemampuan ibu untuk mengambil keputusan yang berdampak luas pada 
kehidupan seluruh anggota keluarga menjadi dasar penyediaan pola pengasuhan yang tepat dan bermutu bagi anak termasuk asuhan gizi.

\section{Daftar Pustaka}

1. Depkes RI. Pedoman Pelaksanaan Stimulasi, Deteksi Din idan Intervensi Dini Tumbuh Kembang Anak.[monographonline]. Jakarta: Depkes RI; 1997 [di akses tanggal 20 Mei 2014]. http://www.depkes.go.id

2. Depkes RI.Pelayanan Stimulasi Deteksi Intervensi Dini Tumbuh Kembang Anak. [monographonline]. Jakarta: Depkes RI; 2010 [di akses tanggal 20 Mei 2014]. http://www.depkes.go.id

3. Hendra. dkk. Permasalahan Umum Kesehatan Anak Usia Prasekolah.[monograph online]. [di akses tanggal 20 Mei 2013]. http://www.permasalahan-umum-kesehatan-anak-usiaprasekolah_anugerah\&hendra.html

4. Depkes,RI. Buku Pedoman Stimulasi, Deteksi dan Intervensi Dini, Tumbuh Kembang. Jakarta: Depkes RI; 2005.

5. Susanti, Dewi, 2009. Faktor-faktor yang berhubungan dengan perkembangan anak balita di PAUD Permata Bunda Kelurahan Binuang Kecamatan Pauh Kota Padang Tahun 2009. Riset. Padang

6. Depkes, RI, 2004, Analisis Situasi Gizi dan Kesehatan Masyarakat, Jakarta

7. Risma A. Hubungan antara status pekerjaan ibu dengan status gizi dan perkembangan anak usia 1 -
3 tahun di Kecamatan Kadia Kota Kendiri (Tesis) Semarang: universitas Diponegoro

8. Wiekke O. Hubungan status gizi terhadap status perkembangan motorik anak usia 0-3 tahun (BATITA) di Kecamatan Kejayan Kabupaten Pasuruan (Skripsi). Malang: Universitas Muhammadiyah, 2007.

9. Siti Z. Hubungan Status Gizi dengan Perkembangan Anak Usia 2 sampai 3 Tahun di Wilayah Kerja Puskesmas Gambirsari Kota Surakarta (Skripsi). Surakarta: Universitas Sebelas Maret Surakarta, 2010.

10. Choirunnisa A, Dera A, Achmad S. Hubungan Antara Status Gizi dengan Perkembangan Motorik kasar Anak balita di RSUD Tugurejo Semarang. Jurnal Ilmu Keperawatan dan Kebidanan (Online Jurnal) 2013. (Diunduh 20 Mei 2013). Tersedia dari: http://www.pmb.stikestelogorejo.ac.id.

11. Ni Ketut S, Dewa Ayu R. Hubungan Status Gizi Waktu Lahir dengan Pertumbuhan dan Perkembangan Anak Usia Pra Sekolah di Desa Peguyangan, Kota Denpasar. Jurnal Imu Gizi, Volume 2 Nomor 2 (Online Jurnal) 2011. (Diunduh 16 April 2015). Tersedia dari poltekesdenpasar.ac.id

12. Sari F, Ikeu N, Windy R. Faktor-faktor yang berkontribusi terhadap status gizi balita di kecamatan ciawi kabupaten tasikmalaya.Majalah Keperawatan Unpad (Online Jurnal) 2008. (Diunduh 16 April 2015). Tersedia dari jurnal.unpad.ac.id. 